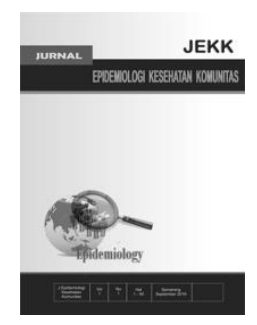

\title{
Hubungan Riwayat Asma dan Riwayat Komorbiditas dengan Kejadian Pneumonia pada Balita (Studi di Wilayah Kerja Puskesmas Bandaharjo Kota Semarang)
}

\author{
Widya $^{*}$, Bagoes Widjanarko**, Apoina Kartini**, Dwi Sutiningsih**, Suhartono** \\ *Magister Epidemiologi Sekolah Pascasarjana, Universitas Diponegoro Semarang \\ **Fakultas Kesehatan Masyarakat Universitas Diponegoro Semarang
}

\begin{abstract}
Background: The incidence of pneumonia in children under five in the working area of the Bandaharjo Community Health Center in 2017 was 443 cases, 2018 was 328 cases, 2019 was 485 cases and in 2020 to June was 231 cases. A history of asthma and a history of comorbidities (anemia and diarrhea) is thought to be one of the determining factors that can cause children under five to develop pneumonia. The purpose of this study was to analyze the history of asthma and comorbid history associated with the incidence of pneumonia in children under five in the Bandaharjo Community Health Center, Semarang City.

Methods: This observational study used a case control design used in this study, with a sample of 80, namely 40 case samples and 40 control samples. The study population was all toddlers who seek treatment and live in the working area of Puskesmas Bandaharjo. The sample of cases in this study were toddlers who had pneumonia in January-June 2020, while the control sample was toddlers who did not have pneumonia 1 in January-June 2020. Data collection was through interviews. Data analysis used chi-square test and multiple logistic regression.

Results: There was a relationship between history of asthma (p; 0.01; OR 19.5; 95\% CI 6.23-61.15), history of comorbidities (p; 0.01; OR 22.91; 95\% CI 5, 97-87,83) with the incidence of pneumonia in children under five.

Conclusion: History of asthma and history of comorbidity have a strong relationship with the incidence of pneumonia in children under five in the working area of the Bandaharjo Community Health Center, Semarang City.
\end{abstract}

Keywords: Pneumonia; Toddlers; Asthma History; History of Comorbidity; Bandaharjo. 


\section{Pendahuluan}

Pneumonia adalah infeksi pernapasan akut yang disebabkan oleh infeksi bakteri, virus, atau jamur yang menyerang paru-paru terutama alveoli. Pada pneumonia anak, alveoli akan terisi dengan nanah atau cairan lain yang mengakibatkan kesulitan bernafas, rasa sakit saat bernafas, kekurangan asupan oksigen dan berisiko tinggi kematian. ${ }^{1}$

Pneumonia merupakan penyebab dari $16 \%$ kematian balita, yaitu sebanyak 920.136 balita di tahun 2015. Menurut laporan WHO, lebih dari 50\% kasus pneumonia berada di Asia Tenggara dan Sub-Sahara Afrika. ${ }^{2}$ Indonesia menduduki peringkat ke 7 sebagai negara penyumbang kematian balita akibat pneumonia, diperkirakan terdapat 25.000 balita meninggal akibat pneumonia. ${ }^{3}$

Jumlah kasus pneumonia pada balita di Indonesia pada tahun 2017 sebanyak 511.343 kasus, dengan angka kesakitan (IR = Incidence Rate) pneumonia sebesar 26.769 per 1.000 .000 balita. ${ }^{4}$ Angka kematian akibat pneumonia pada balita tahun 2016 sebesar $0,22 \%$ pada tahun 2017 menjadi 0,34\%. .,6 $^{5}$

Menurut Profil Kesehatan Indonesia pada tahun 2015 tercapai $14,62 \%$ sedangkan target sebesar 20\%, tahun 2016 tercapai 28,07\% dari target 30\%, tahun 2017 tercapai 42,6\% dari target $40 \%$. Tahun 2018 tercapai sebesar $43 \%$ dari target 50\%. Pada tahun 2018 tidak mencapai target yakni $50 \%$, namun bila dilihat capaiannya meningkat dari tahun sebelumnya dengan angka kematian sebesar $0,08 \%{ }^{7}$

Berdasarkan Profil Kesehatan Jawa Tengah, penemuan dan penanganan pneumonia pada balita tahun 2016 adalah sebesar 59.650 kasus dengan IR pneumonia sebesar 2.739 per 100.000 balita, meningkat pada tahun 2017 menjadi 59.995 kasus dengan IR pneumonia sebesar 2.787 per 100.000 balita dan menempati urutan ke-3 dengan jumlah kasus pneumonia tinggi di Indonesia. ${ }^{4,8}$

Menurut Profil Dinas Kesehatan Kota Semarang yakni bidang P2P, kasus pneumonia ditemukan dan ditangani pada tahun 2017 sebesar 6604 kasus, sedangkan pada tahun 2018 mengalami penurunan sebesar 6477 dan pada tahun 2019 mengalami peningkatan sebesar 8879 kasus. $^{9}$
Puskesmas Bandarharjo merupakan puskesmas dengan jumlah kasus pneumonia balita tinggi di Kota Semarang. Berdasarkan data Rekapitulasi Laporan Bulanan Penderita ISPA, jumlah kasus pneumonia balita di wilayah kerja Puskesmas Bandarharjo pada tahun 2017 sebesar 443 kasus (35\%), tahun 2018 sebesar 328 kasus (26\%), tahun 2019 sebesar 485 kasus (39\%), tahun 2020 sebesar 231 sampai dengan bulan Juni 2020. Angka kematian (CFR) akibat pneumonia dan pneumonia berat di wilayah kerja Puskesmas Bandarharjo pada tahun 2017 menjadi 0,2\%. ${ }^{9}$

Faktor yang menyebabkan terjadinya suatu penyebaran penyakit sangat di pengaruhi oleh 3 faktor yaitu Angent, Host dan Enveropment. Dengan melihat kasus kejadian pneumonia pada balita yang ada diduga bahwa faktor intrinsik dari balita diduga merupakan salah satu faktor determinan yang dapat menyebabkan balita terkena pneumonia.

Balita dengan riwayat asma/mengi mempunyai risiko pneumonia sebesar 4,8 kali dibandingkan dengan anak yang tidak mempunyai riwayat asma/mengi. Hal ini disebabkan karena balita dengan riwayat asma memiliki risiko saluran pernafasan yang cacat, integritas lender dan sel bersila terganggu dan penurunan humoral/imunitas selular lokal maupun sistemik. ${ }^{10}$

Komorbiditas (penyakit penyerta) secara signifikan meningkatkan keparahan pneumonia, termasuk kebutuhan oksigen dan jumlah kematian. Komorbiditas secara signifikan terkait dengan lebih banyak komplikasi dan kebutuhan untuk radiografi dada. ${ }^{11}$ Penyakit yang muncul bersamaan seperti anemia, penyakit jantung bawaan, diare, kondidiasis oral, asma bronkial, bronkiolitis, tonsilofaringitis akut, hipotiroid kongenital, kejang demam. Sebuah studi menemukan bahwa $83 \%$ dari 43 anak-anak dengan pneumonia antara 3-5 tahun memiliki hemoglobin kurang dari $11 \mathrm{~g} / \mathrm{dL}$. Penelitian prospektif lainnya menyebutkan bahwa anemia pada anak merupakan faktor risiko terjadinya infeksi respiratorik akut bawah (IRA-B), kejadiannya 5,75 kali lebih besar dari pada kelompok tanpa anemia. ${ }^{12}$

Berdasarkan uraian diatas sehingga perlu dilakukan penelitian mengenai hubungan 
riwayat asma dan riwayat komorbiditas dengan kejadian pneumonia pada balita di wilayah kerja Puskesmas Bandaharjo Kota Semarang.

\section{Metode}

Penelitian ini adalah sebuah penelitian studi epidemiologic yang bersifat observasional dengan menggunakan rancangan case control bertujuan untuk menganalisa atau mengukur derajat hubungan antara riwayat asma dan riwayat komorbiditas dengan kejadian pneumonia pada balita. Populasi kasus yaitu seluruh balita yang menurut rekam medis menderita pneumonia yang pasien rawat jalan bertempat tinggal dan berobat di Puskesmas Bandarharjo Kota Semarang yakni mulai bulan Januari s.d Juni 2020 tercatat sebanyak 231 balita. Populasi kontrol yaitu seluruh balita yang menurut rekam medis tidak menderita pneumonia yang pasien rawat jalan bertempat tinggal dan berobat di Puskesmas Bandarharjo Kota Semarang yakni mulai bulan Januari s.d Juni 2020 tercatat sebanyak 7.436 balita

Jumlah sampel sebanyak 80 balita terdiri dari 40 sebagai kasus dan 40 sebagai kontrol. Sampel kasus dalam penelitian ini adalah balita yang berobat (pasien rawat jalan) di wilayah kerja Puskesmas Bandarharjo Kota Semarang yakni mulai bulan Januari s.d Juni 2020 dan dinyatakan menderita pneumonia berdasarkan diagnosis dokter, balita yang berumur 1-5 tahun, balita dengan status gizi baik, dan status imunisasi lengkap. Sampel kontrol dalam penelitian ini adalah balita yang berobat (pasien rawat jalan) di wilayah kerja Puskesmas Bandarharjo Kota Semarang yakni mulai bulan Januari s.d Juni 2020, tetapi tidak dinyatakan menderita pneumonia berdasarkan diagnosis dokter. Penentuan kontrol dalam penelitian ini adalah menggunakan teknik mencocokan (matching) dengan sampel kasus. Variabel yang dicocokkan dalam penelitian ini adalah umur 1-5 tahun, status gizi baik dan status imunisasi lengkap. Pengambilan sampel untuk kelompok kotrol dilakukan secara purposive yaitu tetangga sekitar sampel kasus yang memiliki karakteristik yang sama dengan kelompok kasus.

Penelitian menggunakan data sekunder berupa data dari Dinas Kesehatan Kota
Semarang dan dari Puskesmas Bandaharjo serta data primer berupa wawancara dengan instrumen kuisioner melalui kunjungan rumah yang dilakukan oleh petugas kesehatan dan peneliti terhadap responden kasus dan kontrol

Analisis data penelitian dilakukan secara univariat, bivariat dan multivariat untuk melihat distribusi dan frekuensi dari masingmasing variabel independent yaitu riwayat asma dan riwayat komorbiditas terhadap variabel dependen yaitu kejadian pneumonia pada balita. Kemudian dianalisis secara bivariat untuk melihat hubungan antara variabel independen yang telah dikategorikan terhadap variabel dependen berupa kategorik dengan menggunakan uji chi-square selanjutnya analisis multivariat dengan mengabungkan yang berpengaruh secara signifikan dikelompokkan dan dengan menggunakan analisis regresi logistik berganda. ${ }^{9}$ Penelitian ini telah mendapatkan ijin etik dari Komisi Etik Penelitian Kesehatan Fakultas Kedokteran Universitas Diponegoro Semarang.

\section{Hasil Penelitian}

\section{Distribusi frekuensi riwayat asma dan riwayat komorbiditas dengan kejadian pneumonia pada balita}

Berdasarkan tabel 1 diketahui bahwa balita penderita pneumonia (kasus) sebanyak 40 dan balita tidak pneumonia (kontrol) sebanyak 40 di wilayah kerja Puskesmas Bandarharjo, menunjukan bahwa proporsi riwayat asma pada kelompok kasus sebesar $77,5 \%$, sedangkan pada kelompok kontrol sebesar $15 \%$.

Balita yang memiliki riwayat komorbiditas bahwa proporsi balita yang memiliki riwayat komorbiditas pada kelompok kasus sebesar $65 \%$, dengan jenis komorbiditas yaitu diare sebesar 50\%. Sedangkan pada kelompok kontrol sebesar 7,5\%. 
Tabel 1 Distribusi Frekuensi riwayat asma dan riwayat komorbiditas dengan kejadian pneumonia pada balita di Wilayah Kerja Puskesmas Bandaharjo

\begin{tabular}{llcccc}
\hline \multirow{2}{*}{ No } & \multicolumn{1}{c}{ Variabel } & \multicolumn{2}{c}{ Kasus } & \multicolumn{2}{c}{ Kasus } \\
\cline { 3 - 6 } & & $\mathbf{n}$ & $\mathbf{\%}$ & $\mathbf{\%}$ & $\mathbf{\%}$ \\
\hline \multirow{2}{*}{1} & Riwayat asma & 31 & 77,5 & 6 & 15,0 \\
& Ya & 9 & 22,5 & 34 & 85,0 \\
& Tidak & & & & \\
& Riwayat Komorbiditas & & & & \\
2 & Ya & 26 & 65,0 & 3 & 7,5 \\
& Tidak & 14 & 35,0 & 37 & 92,5 \\
& Jenis Komorbiditas & & & & \\
3 & Diare & 20 & 50,0 & 3 & 7,5 \\
& Anemia & 6 & 15,0 & 0 & 0,0 \\
& Tidak ada & 14 & 35,0 & 37 & 92,5 \\
\hline
\end{tabular}

\section{Analisis hubungan riwayat asma dengan kejadian pneumonia pada balita}

Berdasarkan tabel 2 menunjukan bahwa proporsi riwayat asma pada kelompok kasus sebesar 77,5\%, sedangkan pada kelompok kontrol sebesar 15\%. Hasil analisis menggunakan uji chi-square menunjukan nilai $p=0,01$ dan $\mathrm{OR}=19,5 ; \mathrm{CI} 95 \%(6,23-61,15)$, ( $p$ value $\leq 0,05$ ) yang berarti ada hubungan antara riwayat asma dengan kejadian pneumonia pada balita di wilayah kerja Puskesmas Bandarharjo Kota Semarang.

Tabel 2 Hasil analisis hubungan riwayat asma dengan kejadian pneumonia pada balita di wilayah Kerja Puskesmas Bandaharjo Kota Semarang

\begin{tabular}{lccccccc}
\hline \multirow{2}{*}{$\begin{array}{c}\text { Riwayat } \\
\text { asma }\end{array}$} & \multicolumn{2}{c}{ Kejadian Pneumonia } & p- & OR & \multirow{2}{*}{$\begin{array}{c}\mathbf{9 5 \%} \\
\text { Kas })\end{array}$} \\
\cline { 2 - 5 } & $\mathrm{n}$ & $\%$ & $\mathrm{n}$ & $\%$ & & & \\
\hline Ya & 31 & 77,5 & 6 & 15 & & & $(6,23-$ \\
Tidak & 9 & 22,5 & 34 & 85 & 0,01 & 19,5 & $61,15)$ \\
Total & 48 & 100 & 48 & 100 & & & \\
\hline
\end{tabular}

\section{Analisis hubungan riwayat komorbiditas dengan kejadian pneumonia pada balita}

Berdasarkan tabel 3 proporsi balita yang memiliki riwayat komorbiditas pada kelompok kasus sebesar $65 \%$, dengan jenis komorbiditas yaitu diare sebesar 50\%. Sedangkan pada kelompok kontrol sebesar 7,5\%. Hasil analisis menggunakan uji chi-square diperoleh nilai $p$ $=0,01$ dan $\mathrm{OR}=22,91$; CI 95\% (5,97-87,83), ( $p$ value $\leq 0,05$ ) yang berarti ada hubungan antara riwayat komorbiditas dengan kejadian pneumonia pada balita di wilayah kerja Puskesmas Bandarharjo Kota Semarang.

Tabel 3 Hasil analisis hubungan riwayat asma dengan kejadian pneumonia pada balita di wilayah Kerja Puskesmas Bandaharjo Kota Semarang

\begin{tabular}{|c|c|c|c|c|c|c|c|}
\hline \multirow{3}{*}{$\begin{array}{c}\text { Riwayat } \\
\text { komorbidit } \\
\text { as }\end{array}$} & \multicolumn{4}{|c|}{ Kejadian Pneumonia } & \multirow{3}{*}{$\begin{array}{c}\text { p- } \\
\text { value }\end{array}$} & \multirow{3}{*}{ OR } & \multirow{3}{*}{$\begin{array}{c}(95 \% \\
\text { CI })\end{array}$} \\
\hline & \multicolumn{2}{|c|}{ Kasus } & \multicolumn{2}{|c|}{ Kontrol } & & & \\
\hline & $\mathrm{n}$ & $\%$ & $\mathrm{n}$ & $\%$ & & & \\
\hline $\mathrm{Ya}$ & 26 & 65 & 3 & 7,5 & \multirow{3}{*}{0,01} & \multirow{3}{*}{22,91} & \multirow{3}{*}{$\begin{array}{l}(5,97- \\
87,83)\end{array}$} \\
\hline Tidak & 14 & 35 & 37 & 92,5 & & & \\
\hline Total & 48 & 100 & 48 & 100 & & & \\
\hline
\end{tabular}

\section{Multivariat}

Selanjutnya dilakukan dengan beberapa tahapan dalam regresi logistik ganda dengan metode enter dengan uji signifikan yang berbeda pada setiap tahapnya diantaranya $\mathrm{p}$ value $<0,25$, dan terdapat pengaruh apabila $\mathrm{p}$ value $<0,05$.

Tabel 4 Hasil analisis multivariat antara riwayat asma dan riwayat komorbiditas dengan kejadian pneumonia pada balita di wilayah Kerja Puskesmas Bandaharjo Kota Semarang

\begin{tabular}{lcccc}
\hline \multicolumn{1}{c}{ Variabel } & $\boldsymbol{\beta}$ & p-value & OR & 95\% CI \\
\hline Riwayat Asma & 2,105 & 0,002 & 8,210 & $2,103-32,055$ \\
Riwayat & 2,522 & 0,001 & 12,450 & $2,669-58,073$ \\
Komorbiditas & & & &
\end{tabular}

Berdasarkan tabel 4 bahwa faktor risiko riwayat komorbiditas (penyakit penyerta) dengan OR sebesar 12,45 artinya riwayat penyakit penyerta (komorbiditas) mempunyai peluang 12,45 kali menyebabkan pneumonia pada balita.

\section{Pembahasan}

\section{Hubungan riwayat asma dengan kejadian pneumonia pada balita}

Anak-anak yang memiliki riwayat asma akan mengalami peningkatan risiko terkena radang paru-paru sebagai komplikasi dari influenza. ${ }^{13}$ Penelitian yang dilakukan oleh Sunyataningkamto (2004) bahwa anak-anak dengan riwayat mengi (asma) berisiko terkena pneumonia sebesar 4,8 kali dibandingkan dengan anak yang tidak mempunyai riwayat mengi (asma), karena anak-anak dengan 
riwayat mengi memiliki risiko saluran pernafasan yang cacat, intigritas lender dan sel barsilia terganggu dan penurunan hormonal (immunitas) selular lokal maupun sistemik. ${ }^{14}$

Hasil penelitian ini sejalan dengan teori dan didukung dengan penelitian yang dilakukan oleh Sunyataningkamto (2004), membuktikan bahwa ada hubungan antara riwayat asma pada balita dengan kejadian pneumonia pada balita ( $p$ value 0,01). Berdasarkan penelitian ini mengungkapkan bawha balita yang mempunyai riwayat asma 19,5 kali terkena pneumonia dibandingkan dengan balita yang tidak mempunyai riwayat asma.

\section{Hubungan riwayat komorbiditas dengan kejadian pneumonia pada balita}

Komorbiditas secara signifikan meningkatkan keparahan pneumonia, termasuk kebutuhan akan oksigen dan jumlah kematian. Anak-anak yang memiliki penyakit kronis yang terjadi bersamaan mungkin memiliki kekebalan yang menurun sehingga mereka lebih rentan terhadap penyakit yang parah. ${ }^{15}$

Penelitian Nuryati dan Nyimas Heny menunjukkan bahwa penyakit penyerta memiliki hubungan yang signifikan dengan kekambuhan pneumonia ( $\mathrm{p}=0,007)$, bahwa antara penyakit penyerta dengan kekambuhan pneumonia ada hubungan yang kuat karena hampir semua pneumonia berulang disebabkan oleh keadaan atau penyakit yang mendasari. ${ }^{16}$ Penelitian yang dilakukan di Tanzania (2017) juga menunjukan bahwa komorbiditas secara signifikan terkait dengan lebih banyak komplikasi dan kebutuhan akan radiografi dada $(\mathrm{p}<0,05) \cdot{ }^{17}$

Hasil penelitian ini sejalan dengan teori dan didukung dengan penelitian yang sebelumnya telah dilakukan diatas, membuktikan bahwa ada hubungan antara riwayat komorbiditas (penyakit penyerta) pada balita dengan kejadian pneumonia pada balita ( $p$ value 0,01 ), banyak ditemukan balita dengan riwayat komorbiditas diare yaitu sebesar 50\%, sedangkan anemia sebesar $15 \%$. Berdasarkan penelitian ini mengungkapkan bawha balita yang mempunyai riwayat penyakit penyerta (komorbiditas) 22,91 kali terkena pneumonia dibandingkan dengan balita yang tidak mempunyai riwayat penyakit penyerta (komorbiditas).

\section{Kesimpulan}

Terdapat hubungan antara riwayat asma ( $p$ value 0,01, OR 19,5 CI 95\% (6,23-61,15) dan riwayat momorbiditas ( $p$-value 0,01 , OR 22,91; CI 95\% (5,97-87,83) dengan kejadian pneumonia

\section{Ucapan Terima Kasih}

Terima kasih kepada pihak Dinas Kesehatan Kota semarang, dan Kepala Puskesmas Bandaharjo serta ibu kader yang telah memberikan kontribusi dalam pengumpulan data dan melakukan kegiatan observasi lapangan.

\section{Daftar Pustaka}

1. World Health Organization. 2008. Epidemic-prone and pandemic-prone acute respiratory diseases: Infection prevention and control in helath-care facilities. Vol. 53. Geneva: WHO Press: 27-29.

2. World Health Organization (WHO). 2011. Pneumonia [Internet]. Fact sheet No. 331.2011. Available from: www.who.int/ mediacentre/factsheets/fs331/en.

3. United Nations Children's Fund. 2016. Ending child deaths from pneumonia and diarrhoea. UNICEF.2016.p. 45-7.

4. Kementerian Kesehatan Republik Indonesia. 2016. Profil Kesehatan Indonesia. Jakarta: Kementerian Kesehatan Republik Indonesia.

5. Ditjen PPM-PL DR. 2007. Data tahunan Subdit ISPA: 1-13.

6. Balitbang DR. Riskesdas. 2017: 23. 
7. Kementrian Kesehatan Republik Indonesia. 2018. Profil Kesehatan Indonesia.

8. Dinas Kesehatan Provinsi Jawa Tengah. 2016. Profil Kesehatan Provinsi Jawa Tengah: 47-83.

9. Bagian KIA. 2019. Data Kejadian Pneumonia Pada Balita di Puskesmas Bandaharjo 2017-2019.

10. Sunyataningkamto. 2004. The role of indoor air pollution and other factors in the incidence of pneumonia in under-five children. Pediatr Indones. 44:1-2.

11. Caggiano $\mathrm{S}$, Ullmann $\mathrm{N}$, de Vitis $\mathrm{E}$, Trivelli M, Mariani C, Podagrosi M, et al. 2017. Factors that negatively affect the prognosis of pediatric community-acquired pneumonia in district hospital in Tanzania. Int J Mol Sci. 18(3).

12. Ramakrishnan K HP. 2006. Hemoglobin level as a risk factor for lower respiratory tract infections. Indian $\mathrm{J}$ Pediatr. 2006;73:881-3.

13. WHO UNICEF. 2006. Pneumonia: The forgotten killer of children.

14. Sunyataningkamto dkk. 2004. The role of indoor air pollution and other factors in the incidence of pneumonia in under-five children. Pediatr Indones. 2004;44:1-2.

15. Suwanjutha S RS et al. 2012. Risk factors associated with morbidity and mortality of pneumonia in Thai children under 5 years. Southeast Asian J Trop Med Public Heal. 2012;25(1):60-6.

16. Nuryati NH. 2013. Faktor-faktor yang berhubungan dengan kekambuhan pada anak balita dengan pneumonia di ruang rawat inap RSAB harapan kita.
17. Caggiano S, Ullmann $\mathrm{N}$, de Vitis $\mathrm{E}$, Trivelli M, Mariani C, Podagrosi M, et al. 2017. Factors that negatively affect the prognosis of pediatric community-acquired pneumonia in district hospital in Tanzania. Int J Mol Sci. 18(3):1-11. 